\title{
IAMJ
}

INTERNATIONAL

AYURVEDIC

MEDICAL JOURNAL

Research Article

ISSN: 2320-5091

Impact Factor: 6.719

\section{ROLE OF ASPHOTA (HEMIDESMUS INDICUS R.BR.) KSHARASUTRA IN THE MANAGEMENT OF LOW-ANAL FISTULA}

\section{$\underline{\text { V.P. Rechana }}{ }^{1}, \underline{\text { V.V.Soumya }}{ }^{2}$}

${ }^{1}$ Final year PG scholar Department of Shalyatantra, Pankajakasthuri Ayurveda Medical College and Post Graduate Centre, Thiruvananthapuram, Kerala, India

${ }^{2}$ M.S., Assistant Professor, Department of Shalyatantra, Pankajakasthuri Ayurveda Medical College and Post Graduate Centre, Thiruvananthapuram, Kerala, India

Corresponding Author: rechanavp@gmail.com

https://doi.org/10.46607/iamj0209122021

(Published Online: December 2021)

Open Access

(C) International Ayurvedic Medical Journal, India

Article Received: 17/10//2021 - Peer Reviewed: 30/10/2021 - Accepted for Publication 31/10/2021

\section{Check for updates}

\begin{abstract}
In this modern era, due to a sedentary lifestyle and improper dietary habit digestive disorder shows greater incidence. Among them, fistula-in-ano is troubleshooting one, which is a communicating tract between two epithelial surfaces lined by granulation tissues. Due to the higher recurrence rate and postoperative complication fistula-inano is a headache in the present era. In Ayurvedic classics, Ksharasutra prayoga is mentioned for the treatment of Nadi Vrana, which can be adopted in the management of anal fistula. The objective of the present study was to be evaluated the efficacy of Asphota Kshara sutra in the management of low anal fistula. The clinical trial was conducted in OPD and IPD of Shalyatantra department at Pankajakasthuri Ayurveda Medical College. The intervention was ligation of the fistulous tract with Asphota Ksharasutra. 25 subjects were selected satisfying inclusion and exclusion criteria. The clinical assessment was done before treatment, after treatment and follow up on the 30th day after cutting through of the tract. The assessment was done based on parameters prepared for anal fistula by Paul $\mathrm{O}$ Madson and Peter. Pain, burning sensation, inflammation, itching, discharge and unit cutting time was statistically analysed in different periods. Outcome variables were analysed statistically by using the Friedman test and Wilcoxson signed-rank rest, and a conclusion was drawn. Pain, burning sensation, inflammation, discharge, itching was effectively managed using Asphota Ksharasutra. The unit cutting time of Aspota ksharasutra was found to be more
\end{abstract}


than standard Ksharasutra. The result showed that Aspota Ksharasutra is effective in the management of low anal fistula.

Keywords: Fistula-in-ano; Asphota ksharasutra.

\section{INTRODUCTION}

Ayurveda is one of the holistic healing systems, which apart from providing various therapeutic measures for various diseases, emphasizes maintenance and which help in the promotion of health and prevention of diseases through diet and lifestyle regimens. Out of eight branches of Ayurveda Shalyatantra is the pioneer of surgery and Acharya Susrutha is the real torch bearer of surgical practitioners and the people considers him as the 'father of surgery'. He had laid down the unique principles regarding surgical treatment like ksharasutra, agnikarma, rakthamoksha, and shastrakarma. Among them, the ksharakarma is the most important para surgical procedure and ksharasutra is the chief piece of work of ksharakarma.

The anal canal is the site of many diseases. Most conditions arising in this area are incapacitating and interfere with the quality of life. Among them, bhagandara is a troubleshooting one. The tearing of baga, guda and vasthi with acute pain is known as bhagandara. This disease starts as a pidaka or boil which suppurates and burst open to form bhagandara ${ }^{1,2,3}$. The surgical management of bhagandara (fistula-in-ano) carries several complications and a higher recurrence rate. To overcome this problem ksharasutra therapy has been described $^{4,5,6}$. It is found to be very successful with a very less recurrence rate of $3.8 \%$. This procedure is economical, safe and cost-effective with fewer adverse effects and a higher success rate.

In the present study, the treatment procedure adapted is ksharasutra prayoga. The drug used for the preparation of ksharasutra is Asphota (Hemidesmus indicus $\mathrm{R}$. Br) which is mentioned in ksharapaka vidhi adhya of Susrutha Samhita. Acharya Dalhana explained Asphota as Sariba in his commentary. This drug has Madhura, Tikta Rasa, Sheetha virya and Madhura Vipaka.
The objective of the study is to evaluate the efficacy of Asphota Ksharasutra in the management of low anal fistula.

The aim of the study is a better understanding of fistula-in-ano, to evaluate the efficacy of Asphota ksharasutra in the management of low anal fistula.

\section{Materials and Method}

\section{Trial Design}

The study design is an interventional pre-test and posttest study without a control group. The period of intervention depends on the length of the fistulous tract, till complete cutting of the tract is attained. The present study was done fully adhering to GCP-ICH guidelines with IEC approval. The IEC clearance was obtained vid reference no: PKAMC/IEC/37/19

\section{Study Setting}

OPD and IPD, of Department of Shalyatantra Pankajakathuri Ayurveda Medical College and PG centre, Kattakada, Trivandrum.

\section{Study Population}

Subjects of age group between 18 to 70 years with low anal fistula irrespective of gender. The sample size for the study was 25 considering $10 \%$ dropout.

\section{Sampling Technique}

The subjects were selected by consecutive sampling methods from the OPD and IPD of the Department of Shalyatantra, Pankajakathuri Ayurveda Medical College and PG Centre, Kattakada, Trivandrum till sample size was obtained.

\section{Diagnostic Criteria}

Diagnosed by classical signs and symptoms of Bhagandhara (fistula-in-ano)3

The fistulous tract was confirmed after probing.

\section{Inclusion Criteria}

1. Subjects of age group between 18 to 70 years

2. Subjects were selected irrespective of gender, religion, caste and economic status.

3. Subjects diagnosed with low anal fistula. 


\section{Exclusion Criteria}

1. Subjects with high anal fistula

2. Pregnant women

3. Subjects with uncontrolled Diabetes Mellitus

4. Diagnosed cases of HIV, HBsAg positive patients and cardiovascular patients.

5. Fistula in ano secondary to

- Ulcerative colitis

- Crohn's disease

- Tuberculosis

- Colloidal Carcinoma of the rectum

\section{Assessing criteria}

1. Pain

2. Burning sensation

3. Inflammation

4. Discharge

5. Itching

6. Unit cutting time

Signs and symptoms found were graded based on the scoring system prepared for that by Paul O Madson and Peter.

\section{PAIN}

\begin{tabular}{|l|l|}
\hline Grade 0 & No pain \\
\hline Grade1 & Negligible or tolerable pain. No need for any medicine \\
\hline Grade2 & Localized tolerable pain completely relieved by hot sitz bath. \\
\hline Grade 3 & Intolerable pain, not relieved by sitz bath, relieved by oral analgesics. No sleep disturbance. \\
\hline Grade 4 & Continuous and intolerable pain with sleep disturbance. The patient seeks medical help as early as possible. \\
\hline
\end{tabular}

\section{BURNING SENSATION}

Grade 0

Grade 1

Grade 2

Grade3

Grade4
No burning sensation.

The negligible feeling of burning sensation for a few minutes in a day

Tolerable burning sensation completely relieved by hot sitz bath or local oleation

Tolerable but constant burning sensation relieved by hot sitz bath or local oleation

The unbearable burning sensation makes the patients seek medical help as soon as possible

\section{INFLAMMATION}

\begin{tabular}{|l|l|}
\hline Grade0 & No sign of inflammation around the external opening \\
\hline Grade1 & Very little inflammation around the external opening \\
\hline Grade2 & Inflammation in $1 \mathrm{~cm}$ diameter of the external opening \\
\hline Grade3 & Inflammation in $2 \mathrm{~cm}$ diameter of the external opening \\
\hline
\end{tabular}

\section{DISCHARGE}

\begin{tabular}{|l|l|}
\hline Grade 0 & No sign of any discharge \\
\hline Grade 1 & The occasional appearance of discharge and patients use a single cotton pad in $24 \mathrm{hrs}$ \\
\hline Grade 2 & The frequent appearance of discharge and patient used 3-4 cotton pads in $24 \mathrm{hrs}$ \\
\hline Grade 3 & Increased frequency of discharge and patient use 5-6 cotton pads in 24 hrs \\
\hline Grade 4 & Continuous discharge. \\
\hline
\end{tabular}

\section{ITCHING}

\begin{tabular}{|l|l|}
\hline Grade 0 & No complaint of itching \\
\hline Grade 1 & Negligible itching for a few minutes a day \\
\hline Grade 2 & The occasional sensation of itching \\
\hline Grade 3 & The frequent sensation of itching with 4-6 hours interval \\
\hline Grade 4 & The continuous sensation of itching with 15-30 minutes intervals. \\
\hline
\end{tabular}




\section{Unit cutting time}

Total number of days for cut-through

The initial length of ksharasutra (in $\mathrm{cm}$ )

\section{Withdrawal Criteria}

1. The unwillingness of the subject to continue

2. Adverse drug reaction

\section{Investigation}

○ Haematological examination: $\mathrm{Hb} \%, \mathrm{TC}, \mathrm{DC}$, ESR, RBS

- Coagulation profile: BT, CT

○ X-ray Fistulogram was done in necessary subjects.

\section{Data Collection}

Assessment parameters were collected by personal interview, clinical examination and case record form. The assessment was done before treatment, after treatment (after cutting through of tract) and in follow up period ( $30^{\text {th }}$ day after completing cut through of tract).

\section{Duration of Study}

Total duration 18 months

Period of intervention- depending on the length of the fistulous tract.

\section{Procedure}

All the subjects in the trial group were treated using the Asphota kshara sutra.

\section{Preparation of trial drug-Asphota Kshara sutra} Preparation of Asphota Mridhu Kshara

Raw drugs were collected from an authorized dealer and Ksharasutra was prepared in the Department of Salyatantra, Pankajakasthuri Ayurveda Medical College and Post Graduate Centre, Trivandrum.

The whole plant of asphota was taken, it was dried well and burned on a clean surface, all the ash was collected and kept in a vessel to cool. The next day the whole ash was dissolved in six times of water. Then it was kept undisturbed for 12 hours duration. The next day the mixture was filtered 21 times and the filtrate was heated on the gas furnace in a stainless-steel pot until all water was evaporated and till white amorphous powder was obtained. The amorphous powder obtained was made fine powdered with pestle and mortar and sieved through double layer muslin cloth and kept in an airtight glass container.

\section{Preparation of Asphota Kshara Sutra}

The Asphota kshara sutra was prepared by a repeated coating of snuhi ksheera, asphota kshara and haridra choorna over surgical barbous linen tread no 20. This thread is tied tightly throughout lengthwise in hangers. Each thread on the hanger was smeared with snuhi latex with help of a gauze piece soaked in snuhi latex. This wet hanger is transferred into kshara sutra cabinet. The same process was repeated the next day. Eleven such coatings with snuhi ksheera alone were accomplished. The twelfth coating was done by first smearing the thread with snuhi ksheera and in wet condition, a thread was smeared with asphota kshara. It is again transferred into the cabinet for drying. This process was repeated till seven coatings of snuhi ksheera and asphota kshara is achieved. The final three coatings were completed with snuhi ksheera and fine powder of haridra in the same manner. Thus, twenty-one coatings over the thread were completed.

The order of coating is divided as follows

Table 1: Asphota ksharasutra preparation

\begin{tabular}{|l|l|}
\hline Ingredients & No of coating \\
\hline Snuhi ksheera & 11 \\
\hline Snuhi ksheera + ashpota Mridhu Kshara & 7 \\
\hline Snuhi ksheera + haridra & 3 \\
\hline Total coating & 21 \\
\hline
\end{tabular}

Preservation of Kshara Sutra: After the 21 coatings and exposure to UV rays, each thread was sealed into a glass tube. The tube was open only at the time of use.
Pre-Operative Procedure: After obtaining informed consent, vitals were measured and recorded. The patient was kept nil per oral for at least 4 to 6 hours. Soap water or phosphate enema was given 2 hours before the 
procedure. The later perianal and perineal region was prepared.

Materials used: - Mosquito forceps-2, suture cutting scissors, malleable copper probe, sponge holding forceps, instrument tray, cotton swab, sterile cotton pad, Aspota kshara sutra, micropore.

\section{Operative Procedure}

The patient was kept in lithotomy position and part was prepared by using betadine solution $10 \%$ followed by surgical spirit. Local anaesthesia was given using injection lignocaine hydrochloride $2 \%$ in the presence of a trained surgeon. The patient was advised to relax his thigh and anal sphincter. After reassuring the patient, digital and proctoscopy examinations were conducted. Then a malleable copper probe was inserted through the external opening of the fistula. The tip of the probe was forwarded along the path of least resistance and was guided by the gloved finger in the lumen of the anal canal to support the advancement of the probe towards the internal opening. The tip of the probe was finally directed to come out through the anal orifice. A then suitable length of Asphota kshara was taken and threaded into the eye of the probe. Thereafter the probe was pulled out through the anal orifice to leave the thread behind in the fistulous tract. The two ends of the Ksharasutra were tied together with a moderate tightness outside the anal canal.

Post-Operative Procedure: Blood clots in and around the anal canal and perineal region were cleaned. Then a surgical pad was placed in the area. Haemostasis was attained. Vitals were checked and recorded. The anal dressing was done.

Follow Up: The patient was reviewed every week for wound care and thread change.

\section{Unit Cutting Time}

Unit cutting time of patients lies in the range $4.4-$ 11.3. The calculated average unit cutting time is 7.37 .

\section{Graph 1 unit cutting time}

Average unit cutting time

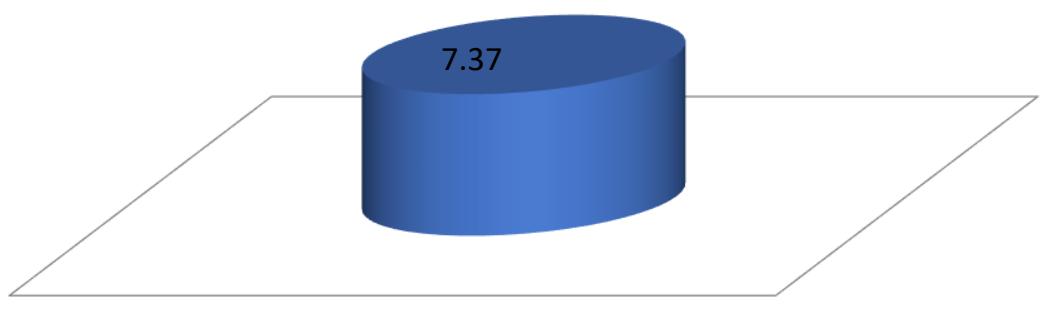

\section{RESULTS - Statistical Analysis and Interpretations}

\section{Effect Of Intervention on Pain}

Table 2: Result of Friedman Test for Pain

\begin{tabular}{|l|l|l|}
\hline Period & Mean rank & SE \\
\hline BT & 3 & 0.206 \\
\hline AT & 1.5 & 0 \\
\hline Follow up & 1.5 & 0 \\
\hline
\end{tabular}

Table 3: Effect of intervention on pain

\begin{tabular}{|l|l|}
\hline Chi-square & 46.00 \\
\hline P-value & $<0.001$ \\
\hline
\end{tabular}


The chi-Square value for the Friedman test for comparing the effect of the intervention on pain at different periods [46.00] was found to be significant and P-value was $<0.001$. Hence rejected the null hypothesis, and accept that there exists a significant difference between at least one pair of the period in terms of pain. As there exists a significant difference between different periods, pairwise comparison was done by using the Wilcoxon Signed-Rank test for finding out which of the periods are different and which are not different.

Table 4: Result of Wilcoxon Signed Rank Tests for Pain

\begin{tabular}{|l|l|l|l|}
\hline Pairs & Calculated value $(\mathbf{Z})$ & P-value & Significance difference \\
\hline BT and AT & -4.238 & $<0.001$ & Present \\
\hline BT and Follow up & -4.238 & $<0.001$ & Present \\
\hline AT and Follow up & 0 & 1.00 & Absent \\
\hline
\end{tabular}

The result shows that there exists a significant difference between the before treatment group and after treatment group at the $1 \%$ level. Also, there exists a significant difference between the before treatment group and follow up group at the $1 \%$ level. There is no significant difference between after treatment group and follow up the group. It means that intervention helps to reduce pain.

Table 5: Assessment of pain based on Paul O Madson \& Peter scoring system

\begin{tabular}{|c|c|c|c|c|c|c|c|c|c|c|}
\hline \multirow[t]{3}{*}{ Period } & \multicolumn{10}{|c|}{ Response } \\
\hline & \multicolumn{2}{|c|}{ Nil } & \multicolumn{2}{|c|}{ Mild } & \multicolumn{2}{|c|}{ Moderate } & \multicolumn{2}{|c|}{ Severe } & \multicolumn{2}{|c|}{ Very severe } \\
\hline & $\mathbf{N}$ & $\%$ & $\mathbf{N}$ & $\%$ & $\mathbf{N}$ & $\%$ & $\mathbf{N}$ & $\%$ & $\mathbf{N}$ & $\%$ \\
\hline BT & 0 & 0 & 5 & 22 & 7 & 30 & 8 & 35 & 3 & 13 \\
\hline AT & 23 & 100 & 0 & 0 & 0 & 0 & 0 & 0 & 0 & 0 \\
\hline Follow up & 23 & 100 & 0 & 0 & 0 & 0 & 0 & 0 & 0 & 0 \\
\hline
\end{tabular}

All the mild, moderate, severe and very severe cases of pain before treatment had been cured after treatment. There were no nil pain cases before treatment. But after treatment nil cases had increased to $100 \%$.

Graph 3: Representation of pain

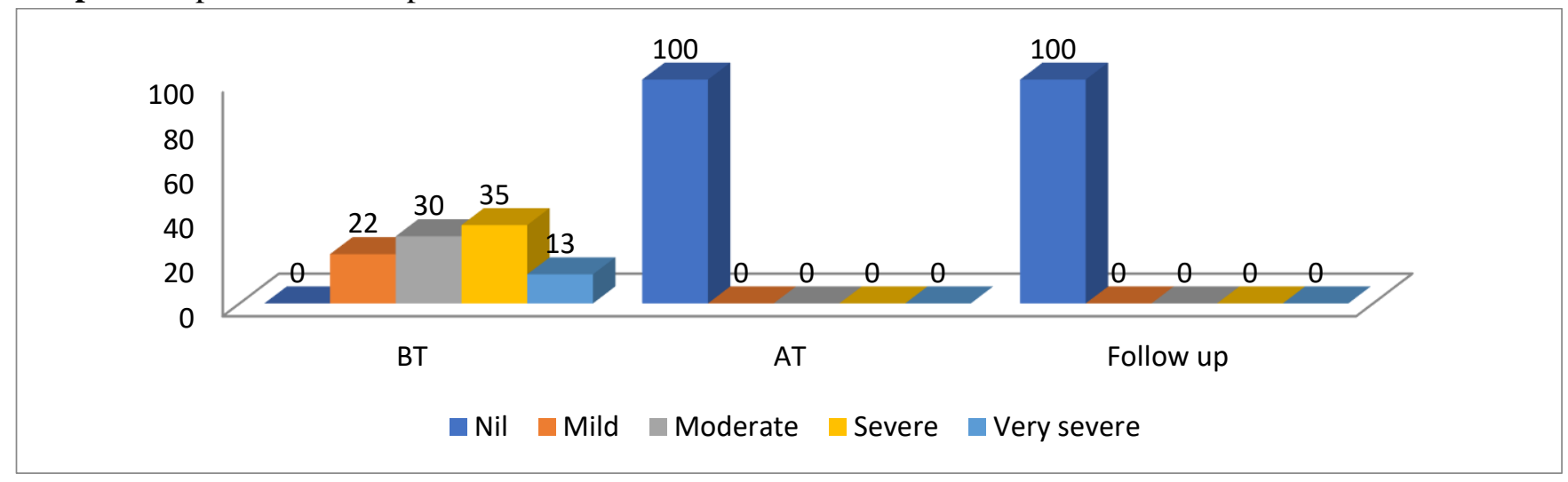




\section{Effect Of Intervention on Burning Sensation}

Table 6: Result of Friedman Test for Burning Sensation

\begin{tabular}{|l|l|l|}
\hline Period & Mean rank & SE \\
\hline BT & 2.74 & 0.224 \\
\hline AT & 1.63 & 0 \\
\hline Follow up & 1.63 & 0 \\
\hline
\end{tabular}

Table 7: Effect of intervention on the burning sensation

\begin{tabular}{|l|l|}
\hline Chi-square & 34.00 \\
\hline P-value & $<0.001$ \\
\hline
\end{tabular}

Chi-Square value for the Friedman test for comparing the effect of the intervention on burning sensation at different periods [34.00] was found to be significant and P-value was $<0.001$. Hence rejected the null hypothesis, and accept that there exists a significant difference between at least one pair of the period in terms of burning sensation. As there exists a significant difference between different periods, pairwise comparison was done by using the Wilcoxon Signed-Rank test for finding out which of the periods are different and which are not different.

Table 8: Result of Wilcoxon Signed Rank Tests for burning sensation

\begin{tabular}{|l|l|l|l|}
\hline Pairs & Calculated value (Z) & P-value & Significance difference \\
\hline BT and AT & -3.674 & $<0.001$ & Present \\
\hline BT and Follow up & -3.674 & $<0.001$ & Present \\
\hline AT and Follow up & 0 & 1.00 & Absent \\
\hline
\end{tabular}

The result shows that there exists a significant difference between before treatment group and after treatment group at $1 \%$ level. Also, there exists a significant difference between the before treatment group and follow up group at the $1 \%$ level. There is no significant difference between after treatment group and follow up the group. It means that intervention helps to reduce the burning sensation.

Table 9: Assessment of burning sensation based on Paul O Madson \& Peter scoring system

\begin{tabular}{|c|c|c|c|c|c|c|c|c|c|c|}
\hline \multirow[t]{3}{*}{ Period } & \multicolumn{10}{|c|}{ Response } \\
\hline & \multicolumn{2}{|c|}{ Nil } & \multicolumn{2}{|c|}{ Mild } & \multicolumn{2}{|c|}{ Moderate } & \multicolumn{2}{|c|}{ Severe } & \multicolumn{2}{|c|}{ Very severe } \\
\hline & $\mathbf{N}$ & $\%$ & $\mathbf{N}$ & $\%$ & $\mathbf{N}$ & $\%$ & $\mathbf{N}$ & $\%$ & $\mathbf{N}$ & $\%$ \\
\hline BT & 6 & 26 & 6 & 26 & 7 & 31 & 4 & 17 & 0 & 0 \\
\hline AT & 23 & 100 & 0 & 0 & 0 & 0 & 0 & 0 & 0 & 0 \\
\hline Follow up & 23 & 100 & 0 & 0 & 0 & 0 & 0 & 0 & 0 & 0 \\
\hline
\end{tabular}

Before treatment, there were $17 \%$ severe cases, $31 \%$ moderate cases and $26 \%$ mild cases of burning sensation. But after treatment, all those cases had cured and nil cases of burning sensation had increased from $26 \%$ to $100 \%$ during the study period. 
Graph 5: Representation of burning sensation

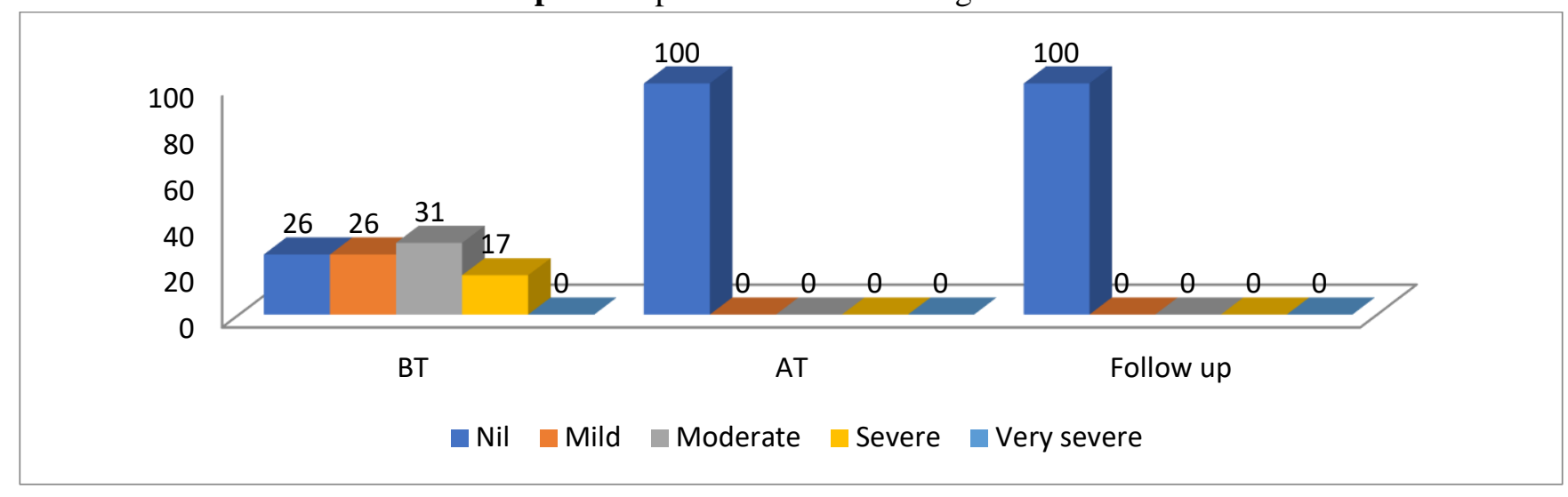

\section{Effect of intervention on inflammation}

Table 10: Result of Friedman Test for inflammation

\begin{tabular}{|l|l|l|}
\hline Period & Mean rank & SE \\
\hline BT & 3 & 0.17 \\
\hline AT & 1.5 & 0 \\
\hline Follow up & 1.5 & 0 \\
\hline
\end{tabular}

Table 11: Effect of intervention on inflammation

\begin{tabular}{|l|l|}
\hline Chi-square & 46.00 \\
\hline P-value & $<0.001$ \\
\hline
\end{tabular}

Chi-Square value for the Friedman test for comparing the effect of the intervention on inflammation at different periods [46.00] was found to be significant and P-value was $<0.001$. Hence rejected the null hypothesis, and accept that there exists a significant difference between at least one pair of the period in terms of inflammation. As there exists a significant difference between different periods, pairwise comparison was done by using the Wilcoxon SignedRank test for finding out which of the periods are different and which are not different.

Table 12: Result of Wilcoxon Signed Rank Tests for inflammation

\begin{tabular}{|l|l|l|l|}
\hline Pairs & Calculated value $(\mathbf{Z})$ & P-value & Significance difference \\
\hline BT and AT & -4.256 & $<0.001$ & Present \\
\hline BT and Follow up & -4.256 & $<0.001$ & Present \\
\hline AT and Follow up & 0 & 1.00 & Absent \\
\hline
\end{tabular}

The result shows that there exists a significant difference between before treatment group and after treatment group at $1 \%$ level. Also, there exists a significant difference between the before treatment group and follow up group at the $1 \%$ level. There is no significant difference between after treatment group and follow up the group. It means that intervention helps to reduce inflammation. 
Table 13: Assessment of inflammation based on Paul O Madson \& Peter scoring system

\begin{tabular}{|c|c|c|c|c|c|c|c|c|}
\hline \multirow[t]{3}{*}{ Period } & \multicolumn{8}{|c|}{ Response } \\
\hline & \multicolumn{2}{|c|}{ Nil } & \multicolumn{2}{|c|}{ Mild } & \multicolumn{2}{|c|}{ Moderate } & \multicolumn{2}{|c|}{ Severe } \\
\hline & $\mathbf{N}$ & $\%$ & $\mathbf{N}$ & $\%$ & $\mathbf{N}$ & $\%$ & $\mathbf{N}$ & $\%$ \\
\hline BT & 0 & 0 & 9 & 39 & 8 & 35 & 6 & 26 \\
\hline AT & 23 & 100 & 0 & 0 & 0 & 0 & 0 & 0 \\
\hline Follow up & 23 & 100 & 0 & 0 & 0 & 0 & 0 & 0 \\
\hline
\end{tabular}

All the mild, moderate and severe cases of inflammation before treatment had cured after treatment. Nil cases had increased from $0 \%$ to $100 \%$ during the study period.

Graph 7: Representation of inflammation

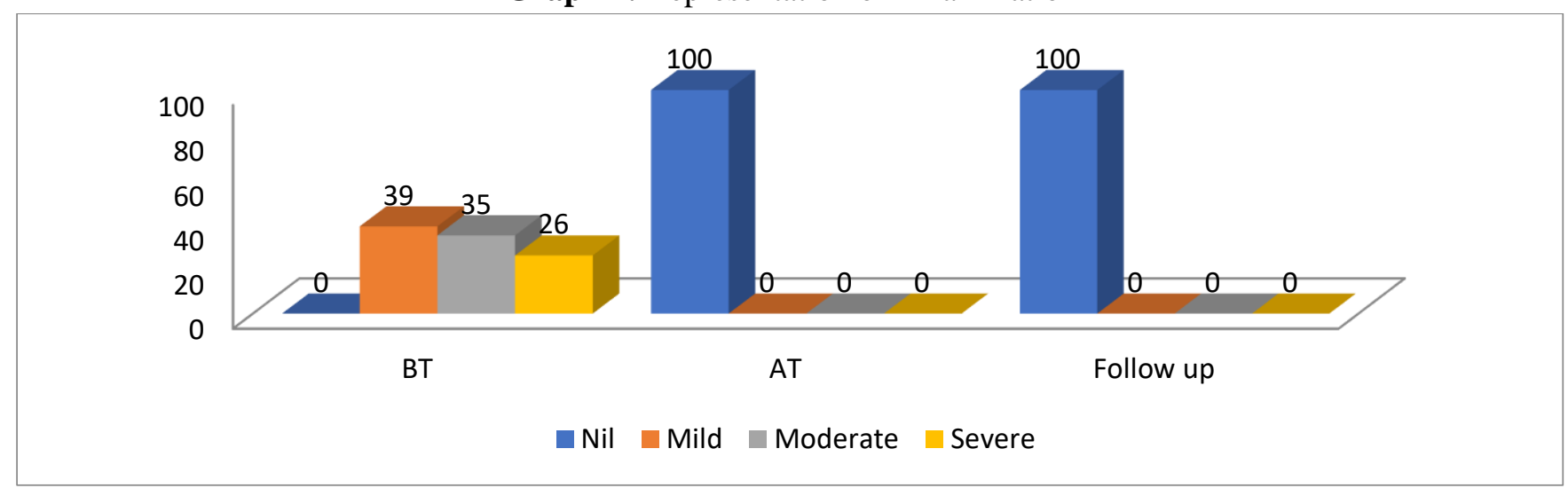

\section{Effect of intervention on discharge}

Table 14: Result of Friedman Test of discharge

\begin{tabular}{|l|l|l|}
\hline Period & Mean rank & SE \\
\hline BT & 2.83 & 0.197 \\
\hline AT & 1.59 & 0 \\
\hline Follow up & 1.59 & 0 \\
\hline
\end{tabular}

Table 15: Effect of intervention on discharge

\begin{tabular}{|l|l|}
\hline Chi-square & 38.00 \\
\hline P-value & $<0.001$ \\
\hline
\end{tabular}

Chi-Square value for the Friedman test for comparing the effect of the intervention on discharge at different periods [38.00] was found to be significant and Pvalue was $<0.001$. Hence rejected the null hypothesis, and accept that there exists a significant difference between at least one pair of the period in terms of discharge. As there exists a significant difference between different periods, pairwise comparison was done by using the Wilcoxon Signed-Rank test for finding out which of the periods are different and which are not different.

Table 16: Result of Wilcoxon Signed Rank Tests on discharge

\begin{tabular}{|l|l|l|l|}
\hline Pairs & Calculated value $(\mathbf{Z})$ & P-value & Significance difference \\
\hline BT and AT & -3.921 & $<0.001$ & Present \\
\hline BT and Follow up & -3.921 & $<0.001$ & Present \\
\hline AT and Follow up & 0 & 1.00 & Absent \\
\hline
\end{tabular}


The result shows that there exists a significant difference between before treatment group and after treatment group at $1 \%$ level. Also, there exists a significant difference between the before treatment group and follow up group at the $1 \%$ level. There is no significant difference between after treatment group and follow up the group. It means that intervention helps to reduce discharge.

Table 17: Assessment of discharge based on Paul O Madson \& Peter scoring system

\begin{tabular}{|c|c|c|c|c|c|c|c|c|c|c|}
\hline \multirow[t]{3}{*}{ Period } & \multicolumn{10}{|c|}{ Response } \\
\hline & \multicolumn{2}{|c|}{ Nil } & \multicolumn{2}{|c|}{ Mild } & \multicolumn{2}{|c|}{ Moderate } & \multicolumn{2}{|c|}{ Severe } & \multicolumn{2}{|c|}{ Very severe } \\
\hline & $\mathbf{N}$ & $\%$ & $\mathbf{N}$ & $\%$ & $\mathbf{N}$ & $\%$ & $\mathbf{N}$ & $\%$ & $\mathbf{N}$ & $\%$ \\
\hline BT & 4 & 17 & 5 & 22 & 11 & 48 & 3 & 13 & 0 & 0 \\
\hline $\mathrm{AT}$ & 23 & 100 & 0 & 0 & 0 & 0 & 0 & 0 & 0 & 0 \\
\hline Follow up & 23 & 100 & 0 & 0 & 0 & 0 & 0 & 0 & 0 & 0 \\
\hline
\end{tabular}

All the mild, moderate and severe cases of discharge before treatment had been cured after treatment. Nil cases had increased from $17 \%$ to $100 \%$ during the study period.

Graph 9: Representation of discharge

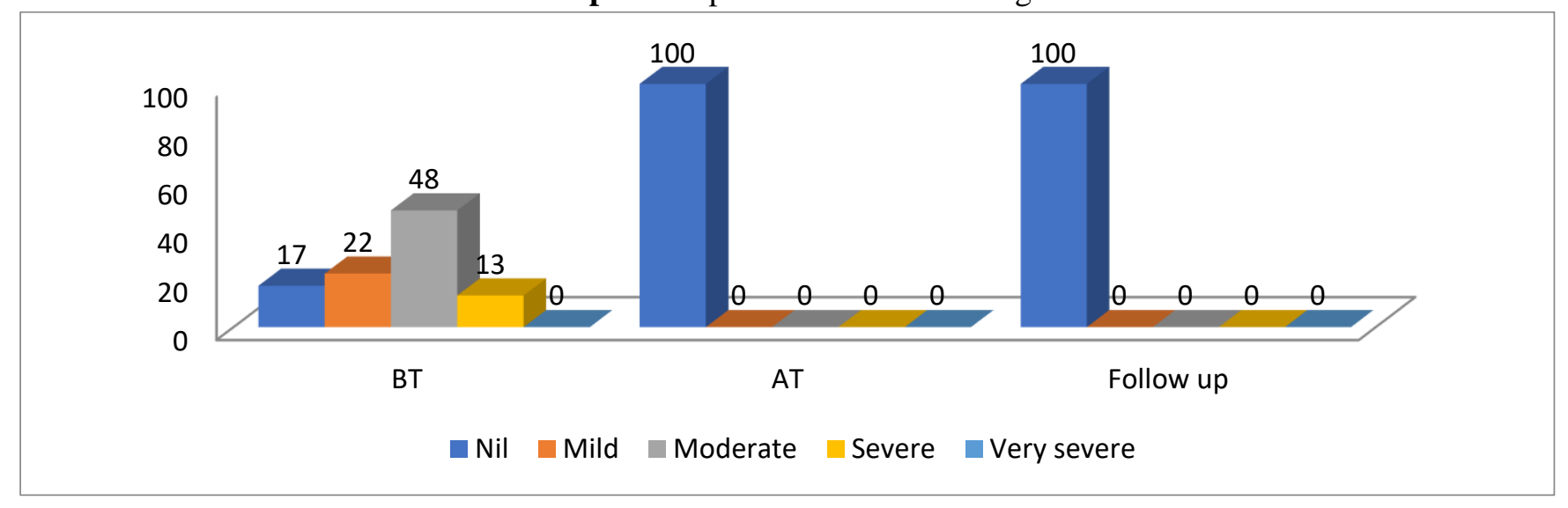

\section{Distribution according to itching}

Table 18: Result of Friedman Test for itching

\begin{tabular}{|l|l|l|}
\hline Period & Mean rank & SE \\
\hline BT & 2.57 & 0.166 \\
\hline AT & 1.72 & 0 \\
\hline Follow up & 1.72 & 0 \\
\hline
\end{tabular}

Table 19: Effect of intervention on itching

\begin{tabular}{|l|l|}
\hline Chi-square & 26.00 \\
\hline P-value & $<0.001$ \\
\hline
\end{tabular}

Chi-Square value for the Friedman test for comparing the effect of the intervention on itching at different periods [26.00] was found to be significant and Pvalue was $<0.001$. Hence rejected the null hypothesis, and accept that there exists a significant difference between at least one pair of the period in terms of itching. As there exists a significant difference between different periods, pairwise comparison was done by using the Wilcoxon Signed-Rank test for finding out which of the periods are different and which are not different. 
Table 20: Result of Wilcoxon Signed Rank Tests for itching

\begin{tabular}{|l|l|l|l|}
\hline Pairs & Calculated value (Z) & P-value & Significance difference \\
\hline BT and AT & -3.286 & $<0.001$ & Present \\
\hline BT and Follow up & -3.286 & $<0.001$ & Present \\
\hline AT and Follow up & 0 & 1.00 & Absent \\
\hline
\end{tabular}

Table 21: Assessment of itching based on Paul O Madson \& Peter scoring system

\begin{tabular}{|c|c|c|c|c|c|c|c|c|c|c|}
\hline \multirow[t]{3}{*}{ Period } & \multicolumn{10}{|c|}{ Response } \\
\hline & \multicolumn{2}{|c|}{ Nil } & \multicolumn{2}{|c|}{ Mild } & \multicolumn{2}{|c|}{ Moderate } & \multicolumn{2}{|c|}{ Severe } & \multicolumn{2}{|c|}{ Very severe } \\
\hline & $\mathbf{N}$ & $\%$ & $\mathbf{N}$ & $\%$ & $\mathbf{N}$ & $\%$ & $\mathbf{N}$ & $\%$ & $\mathbf{N}$ & $\%$ \\
\hline BT & 10 & 43 & 8 & 35 & 5 & 22 & 0 & 0 & 0 & 0 \\
\hline AT & 23 & 100 & 0 & 0 & 0 & 0 & 0 & 0 & 0 & 0 \\
\hline Follow up & 23 & 100 & 0 & 0 & 0 & 0 & 0 & 0 & 0 & 0 \\
\hline
\end{tabular}

There were no severe and very severe cases of itching before treatment. All the mild and moderate cases of itching before treatment had cured after treatment. Nil cases of itching had increased from $43 \%$ to $100 \%$ during the study period.

Graph 11: representation of itching

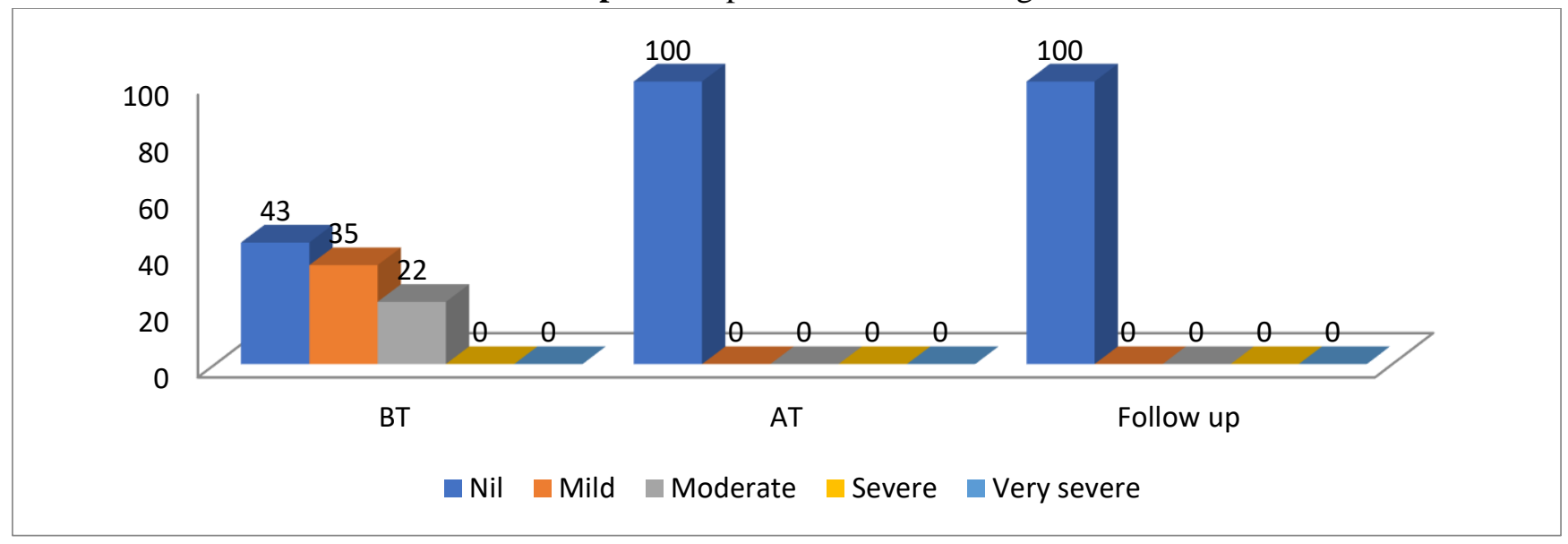

PROBABLE MODE OF ACTION OF ASPHOTA KSHARASUTRA

Asphota drug is having tikta, madhura rasa and also belongs to Madhura vipaka, sheethavirya and tridosha shamaka. It is vatahara because of its Madhura vipaka, pitta samaka because of its sheetha virya and Madhura vipaka, tikta and madhura rasa. Kaphasamaka due to tikta rasa. It is also having the property of kusthaghna, kandughna, raktasodhana and raktapitta hara. The fistula is a tract lined by unhealthy granulation tissue. So, we need a treatment modality that can ensure cutting and healing of the track simultaneously. Tridoshahara, raktapittahara, vranaropana action of asphota along with mechanical cutting action of the thread along with the properties of haridra and snuhi works in the disease.

The caustic property of kshara helps in the destruction of the unhealthy tissue and provide a healthy granulation tissue and promotes healing. ksharasutra helps in cutting and draining the track with simultaneously helping to attain the healing of the track. Raktapitta hara and tridosha hara and vrana ropana property fasten the wound healing. Asphota when made into kshara form which is having more potency, and when applied as ksharasutra has an added effect in managing fistula-in-ano. The post-operative care with sitz bath and daily dressing, pathya karma followed after 
and during treatment might have helped in preventing the recurrence.

The caustic property of the asphota kshara will cause the disintegration of unhealthy granulation by the protein denaturation process. The curcumin content in the haridra act as a catalyst to activate the denaturation process. Along with antimicrobial action haridra and alkaloids present in the snuhi helps in the cutting, draining and healing of the fistulous tract.

\section{DISCUSSION}

\section{Pain}

The pain was the common complaint in all the subjects before treatment. During the treatment period pain gradually decreased, after treatment and in follow up time pain was completely absent in all subjects. The data was statistically analysed using the Friedman test. The P-value was found to be $<0.001$ which rejects the null hypothesis. And pairwise comparison was done using Wilcoxon signed-rank test and observed a significant difference between before treatment and after treatment, before treatment and follow up. There was no significant difference between after treatment and follow up. It means that the intervention helped to reduce pain, and there is no recurrence of pain in follow up period. This result may be due to vatahara property of the drug, vata is the main dosha that causes pain. Vatahara action of the drug is because the Madhura vipaka and asphota Kshara will have similar properties and help in reducing pain. When Asphota is converted to kshara from tridoshaghana and ropana property of kshara will combine with the vranaropana and vranasodhana property of haridra and snuhi respectively and help in reducing pain.

\section{Burning Sensation}

The burning sensation was a common symptom present in all subjects at different levels. During treatment burning sensation gradually decreased and became absent after treatment and follow up. The data were analysed using the Friedman test. The P-value was found to be $<0.001$ which rejects the null hypothesis. Pairwise comparison was done using Wilcoxson signedrank test. The result shows that there exists a significant difference between before treatment, after treatment and before treatment and follow up. And there is no significant between after treatment and follow up. It means that the study intervention helps reduce burning sensation and there is no recurrence of burning sensation in follow up period. This result may be due to pitta samaka action of the drug due to sheetha virya of the drug. so while converting it into kshara Soumya guna of kshara and along with the sheetha virya of Asphota and pitta samaka action of haridra might have helped to reduce the burning sensation.

\section{Inflammation}

Inflammation was present in all the subjects at different grades. During treatment inflammation gradually decreased and became absent after treatment and follow up. The data were analysed using the Friedman test. The P-value was found to be $<0.001$ which rejects the null hypothesis. Pairwise comparison was done using Wilcoxson signed-rank test. The result shows that there exists a significant difference between before treatment, after treatment and before treatment and follow up. And there is no significant between after treatment and follow up. It means that the study intervention helps reduce inflammation and there is no recurrence of inflammation in follow up period. This result may be due to pittashamaka action of the Asphota which is due to madhura rasa, madhuravipaka and sheetha virya. These properties might be maintained while converting it into kshara. Along with shodhahara property of haridra helped in the reduction of inflammation in ksharasutra form.

\section{Discharge}

Before treatment discharge was present in all subjects in variable grades. During treatment discharge gradually decreased and became absent after treatment and follow up. The data were analysed using the Friedman test. The P-value was found to be $<0.001$ which rejects the null hypothesis. Pairwise comparison was done using Wilcoxson signed-rank test. The result shows that there exists a significant difference between before treatment, after treatment and before treatment and follow up. And there is no significant between after treatment and follow up. It means that intervention helped reduce discharge and there was no recurrence of 
discharge in follow up period. This result is probably due to kaphahara property of the drug due to tikta rasa while converting it to kshara the stambaka property of kshara along with kaphahara property of Asphota and haridra might be the probable mode of action to reduce the discharge.

\section{Itching}

Before treatment itching was absent in $43 \%$ of subjects and was present in the rest of the subjects at variable grades. During treatment itching gradually decreased and became absent after treatment and follow up. The data were analysed using the Friedman test. The Pvalue was found to be $<0.001$ which rejects the null hypothesis. Pairwise comparison was done using Wilcoxson signed-rank test. The result shows that there exists a significant difference between before treatment, after treatment and before treatment and follow up. And there is no significant between after treatment and follow up. It means that the intervention helps reduce itching and there is no recurrence of itching in follow up period. This result may be due to kaphahara property of Asphota due to its tikta rasa and also due kusthaghna and kandughna property along with raktashodhana, vishahara action of haridra vishaghna property of snuhi might have helped in reducing itching.

\section{Unit cutting time}

Average unit cutting was evaluated, and the analysis shows that the average unit cutting time was 7.37 days $/ \mathrm{cm}$. The unit cutting time of standard kshara sutra is 7 days $/ \mathrm{cm}^{104}$.so, while analysing the unit cutting time it is assumed here that asphota ksharasutra is not superior to the standard ksharasutra.

\section{CONCLUSION}

In this study, the trial ksharasutra proved its efficacy in the cut-through of the low anal fistulous tract with a unit cutting time (UCT) of 7.37 days $/ \mathrm{cm}$. it is also found to have a significant effect in reducing the clinical symptoms of fistula -in-ano like, pain, inflammation, burning sensation and itching as assessed in the study. It was found to be free from any sort of side effects or adverse reactions during the clinical trial. Thus, the present clinical study proves that Asphota ksharasutra can be used as a safe effective alternative Ksharasutra in treating low anal fistula.

\section{REFERENCES}

1. Susrutha. Bhagandara Nidana. In: Vaidya Jadavji Trikamji Acharya, editor. Susrutha Samhita. Varanasi: Chaukhamba Surbharati Prakashan; 2017. p 282- 4/11.

2. Susrutha. Bhagandara Nidana. In: Vaidya Jadavji Trikamji Acharya, editor. Susrutha Samhita. Varanasi: Chaukhamba Surbharati Prakashan; 2017. p 280- 4/4.

3. Susrutha. Bhagandara Nidana. In: Vaidya Jadavji Trikamji Acharya, editor. Susrutha Samhita. Varanasi: Chaukhamba Surbharati Prakashan; 2017. p280-4/5

4. Agnivesa. Swayathu Chikitsa. In: Vaidya Jadavji Trikamji Acharya, editor. Charaka Samhita. Varanasi: Chaukhamba Krishnadas Academy; 2007. p 490$12 / 97$.

5. Susrutha. Visarpanadisthanaroga Chikitsitam. In: Vaidya Jadavji Trikamji Acharya, editor. Susrutha Samhita. Varanasi: Chaukhamba Surbharati Prakashan; 2017. p468-17/29,30,31,32.

6. Vagbhata. Granthiarbudasleepadaapachinadi Pratishedam. In: Bhisagacharya Harisastri Paradakara Vaidya, editor. Ashtangahrudayam: Varanasi: Chaukhamba Orientalia; 2015. p887- 30/35,36

\section{Source of Support: Nil}

\section{Conflict of Interest: None Declared}

How to cite this URL: P. Rechana \& V.V. Soumya: Role Of Asphota (Hemidesmus Indicus R.Br.) Ksharasutra In The Management Of Low-Anal Fistulav. International Ayurvedic Medical Journal \{online\} 2021 \{cited December 2021\} Available from: http://www.iamj.in/posts/images/upload/2920_2932.pdf 